\title{
ETHNOPEDOLOGY IN PRODUCTION UNITS AT CANTO DA ILHA DE CIMA, SÃO MIGUEL DO GOSTOSO-RN, BRAZIL
}

\author{
ETNOPEDOLOGIA EM UNIDADES DE PRODUÇÃO CANTO DA ILHA DE CIMA, \\ SÃO MIGUEL DO GOSTOSO, RN, BRASIL
}

\author{
Marialdo Santana da CUNHA ${ }^{1}$; Miguel FERREIRA NETO ${ }^{1}$; Jeane Cruz PORTELA ${ }^{1}$; \\ Francisco ERNESTO SOBRINHO ${ }^{1}$; Jucirema Ferreira da SILVA ${ }^{1}$; Nildo da Silva DIAS ${ }^{1}$; \\ Jeska Thayse da Silva Fernandes da CUNHA ${ }^{1}$; Francisco Vanies da Silva $S A^{\mathbf{1}}$ \\ 1. Centro de Ciências Agrárias, Universidade Federal Rural do Semi-Árido - UFERSA, Mossoró-RN, Brasil. miguel@ufersa.edu.br; \\ vanies_agronomia@hotmail.com;
}

\begin{abstract}
Ethnopedological studies in family units tend to contribute to the academy with respect to the importance of knowledge exchange, allowing the understanding on the local reality of a community. The objective of this study was to conduct an ethnopedological study in production units at the Settlement Project Canto da Ilha de Cima - RN, Brazil, and to infer on their interrelationships of knowledge. Participatory workshops and transverse walks were carried out and soils were classified by means of Ethnopedology. The soils were classified using etic and emic approaches, respectively: Inceptisol - CAMBISSOLO HAPLICO Carbonático típico (Terra Boa or Malhada de Boi) (P1); Oxisol - LATOSSOLO AMARELO Eutrófico típico (Terra de Arisco) (P2); Ultisol - ARGISSOLO VERMELHO AMARELO Eutrófico típico (Terra de Arisco Branco Amarelado) (P3); Oxisol - LATOSSOLO AMARELO Eutrófico típico (Terra de Piçarro) (P4); Ultisol ARGISSOLO AMARELO Eutrófico abrúptico (Terra de Arisco) (P5) and Inceptisol - CAMBISSOLO HÁPLICO Tb Eutrófico típico (Terra Boa or Velha Chica) (P6 and P7). In the emic survey, farmers described as fertile and better for agricultural activities the soils in the following areas: "Terra Boa" or "Malhada do Boi" (P1) and "Velha Chica" or "Terra Boa" (P6 and P7), corroborating the etic classification, based on the parent material. The soils in these areas were classified as Inceptisols (CAMBISSOLOS), which have higher natural fertility.
\end{abstract}

KEYWORDS: Soil science. Land use. Semi-arid.

\section{INTRODUCTION}

The application of technical-scientific knowledge can become more advantageous with the aid of an ethnopedological approach. This approach proposes the exchange of knowledge between researchers and farmers in order to build an integrated and applied comprehension, with the objective of recognizing the soil as a natural resource that is complex, dynamic and that operates in conjunction with the other means, including humans (ARAÚJO et al., 2013)

Ethnopedological studies become important because they facilitate the application of traditional knowledge and enable its communication with the scientific community, providing an integrated characterization of soils and landscape, supporting the planning for sustainable use of the lands (MATOS et al., 2014).

Therefore, it is believed that the combination of knowledges, classical and empirical, through the ethnopedological study in family farming production units, allows a better knowledge exchange between the University and the farmers. Thus, the objective of this work was to carry out an ethnopedological study in family farming production units at the Settlement Project Canto da Ilha de Cima, São Miguel do Gostoso - RN, Brazil, using participatory methodologies.

\section{MATERIAL AND METHODS}

\section{Ethnopedological characterization of the study area}

The study was carried out at the Settlement Project Canto da Ilha de Cima (5 $5^{\circ} 7^{\prime} 48^{\prime \prime}$ S, $35^{\circ} 38^{\prime}$ $23^{\prime \prime} \mathrm{W}$ ), in the region of Mato Grande, in the municipality of São Miguel do Gostoso-RN, Brazil. The region has rainy tropical climate with dry summer and mean annual rainfall of $1000 \mathrm{~mm}$. Geologically, the municipality is located in areas within the Potiguar Basin, Cretaceous age, but the bioclastic calcarenites and calcilutites of the Jandaíra Formation are present only in its Southwestern portion. The rest of the area is covered by the Tertiary aged sediments of the Barreiras Group, composed of fine to medium or conglomeratic sandstone, interlayered with siltstone and claystone, dominantly associated with fluvial systems (IDEMA, 2008). 
Five production units were chosen by the farmers, in areas representative of their main agricultural activities, and were georeferenced. Seven soil profiles were opened and sampled in these areas, identified as: area of sheep and goat grazing (APOC - P1), area of beekeeping (AAPI $\mathrm{P} 2$ ), area of agroecological cultivation of vegetables (ACAG - P3 and P4), area of preserved Caatinga (ACP - P5) and area of conventional production "Velha Chica" (AVC - P6 and P7).

The production units were described as follows: A) Sheep and goat grazing area (APOC) $\left(05^{\circ} 06^{\prime} 44^{\prime \prime} \mathrm{S} ; 35^{\circ} 46^{\prime} 30^{\prime \prime} \mathrm{W}\right)$ - cultivated under rainfed conditions with intercropped annual plants: cassava (Manihot esculenta), cowpea (Vigna unguiculata), sweet potato (Ipomoea batatas) and corn (Zea mays); B) Beekeeping area (AAPI) $\left(05^{\circ}\right.$ 06' $51.5^{\prime}$ ' S; $35^{\circ} 45^{\prime} 71.3$ ' W) - referred to by the farmers as "área de capoeira", previously deforested and burned, and currently used for beekeeping (Apis melifera); C) Area of agroecological cultivation of vegetables (ACAG) $\left(05^{\circ} 06^{\prime} 38.2^{\prime}\right.$ ' $\left.\mathrm{S} ; 35^{\circ} 45^{\prime} 90.1^{\prime}, \mathrm{W}\right)$ - intended for collective cultivation, managed by the families; D) Area of preserved Caatinga (ACP) $\left(05^{\circ} 06^{\prime} 62.1^{\prime}\right.$, $\mathrm{S} ; 35^{\circ} 45^{\prime} 31.7^{\prime}$ ' W) - considered as reference for the other samplings, in which the predominant vegetation is hypoxerophilic and hyperxerophilic Caatinga; E) Area of conventional production "Velha Chica" (AVC) (05 $05^{\circ} 17$ '38.9" S; 36 $36^{\circ}$ ' $\left.81.3^{\prime \prime} \mathrm{W}\right)$ - collective area under intercropped cultivation of cassava (Manihot esculenta), cowpea (Vigna unguiculata), sweet potato (Ipomoea batatas), corn (Zea mays) and cotton (Gossypium L.), 'Verde' and 'Mocó' varieties.

Soil classification was carried out using emic (popular knowledge) and etic (scientific knowledge) methodologies. The emic classification used a participatory methodology with the farmers of the Settlement Project, students and academic professionals through transverse walks [i.e., straight walks along the longest extension of the terrain for an exploratory survey of the environment, understanding and writing down all aspects observed by the participants in each one of the different zones crossed (Verdejo, 2006)], besides meetings and workshops in which the areas and profiles were evaluated by visual and tactile tests of some soil attributes such as texture, structure and stickiness, color, physical impediment, position on the landscape and name of the land, according to the knowledge of the farmers, following the methodological model of stratification of environments to construct keys and classifications of soils in the agricultural areas (Adapted from RESENDE; KER, 1991).

The etic classification was based on the Brazilian Soil Classification System (SiBCS) (SANTOS et al., 2018), with morphological, chemical and physical characterization and collection of samples in the respective horizons of each profile. The samples were placed in plastic bags, identified and taken to the Laboratory of Soil, Water and Plant Analysis - LASAP/UFERSA. Then, the samples were air dried, pounded to break up clods and sieved through $2.0-\mathrm{mm}$ mesh to obtain the air-dried fine earth (ADFE) and used in soil physical and chemical analyses.

Physical analyses were: granulometry, obtained by the pipette method using chemical dispersant (sodium hexametaphosphate) and particle density, conducted by the volumetric flask method (TEIXEIRA et al., 2017).

Chemical analyses were: hydrogen potential $(\mathrm{pH})$ in water; electrical conductivity (EC) in water; organic carbon (OC) through wet oxidation of organic matter with potassium dichromate in sulfuric medium; contents of exchangeable calcium $\left(\mathrm{Ca}^{2+}\right)$ and exchangeable magnesium $\left(\mathrm{Mg}^{2+}\right)$ extracted with potassium chloride; exchangeable aluminum $\left(\mathrm{Al}^{3+}\right)$ extracted with $1 \mathrm{~mol} \mathrm{~L} \mathrm{~L}^{-1} \mathrm{KCl}$, analyzed by titration; potential acidity $(\mathrm{H}+\mathrm{Al})$ determined using calcium acetate; and analysis of phosphorus (P), sodium $\left(\mathrm{Na}^{+}\right)$and potassium $\left(\mathrm{K}^{+}\right)$ with Mehlich-1 extractor. The data were used to calculate cation exchange capacity (CEC), sum of bases (SB) and base saturation (V), analyzed according to Teixeira et al. (2017). The tables present the mean values of triplicates for physical and chemical attributes. The results of chemical attributes were interpreted according to the tables of recommendation for the use of correctives and fertilizers in Minas Gerais (ALVAREZ et al., 1999).

The soils were classified using etic and emic approaches: Inceptisol - CAMBISSOLO HÁPLICO Carbonático típico (P1), Oxisol - LATOSSOLO AMARELO Eutrófico típico (P2), Ultisol ARGISSOLO VERMELHO AMARELO Eutrófico típico (P3), Oxisols - LATOSSOLO AMARELO Eutrófico típico (P4), Ultisol - ARGISSOLO AMARELO Eutrófico abrúptico (P5), Inceptisol CAMBISSOLO HÁPLICO Tb Eutrófico típico (P6), and Inceptisol - CAMBISSOLO HÁPLICO Tb Eutrófico típico (P7).

\section{RESULTS AND DISCUSSION}

Table 1 presents the mean values of physical attributes relative to granulometric 
distribution, textural class, particle density and color (morphology). The silt fraction stood out in the class of the Inceptisols (P1, P6 and P7), and highest percentage was found in the sheep and goat grazing area (APOC) (P1) (CAMBISSOLO HAPLICO Carbonático típico). Its textural class was sandy,
CUNHA, M. S. et al.

except in the horizon $2 \mathrm{C}(90-110 \mathrm{~cm})$, which had silty loam texture, indicating young, little weathered soils. Mota et al (2013) found high values of silt fraction in an Inceptisol under soil management systems at the Apodi Plateau, RN.

Table 1. Soil physical attributes in the areas of the family farming production unit Canto da Ilha de Cima, São Miguel do Gostoso / RN.

\begin{tabular}{|c|c|c|c|c|c|c|c|c|}
\hline Area & Hor. & Layer & $\begin{array}{l}\text { Total } \\
\text { Sand }\end{array}$ & Silt & Clay & \multirow[t]{2}{*}{ Textural classification } & $\mathrm{Dp}$ & \multirow[t]{2}{*}{ Color } \\
\hline & & $\mathrm{cm}$ & \multicolumn{3}{|c|}{$\mathrm{g} \mathrm{kg}^{-1}$} & & $\mathrm{~kg} \mathrm{dm}^{-3}$ & \\
\hline APOC & \multicolumn{8}{|c|}{ Profile 1 Inceptisol (CAMBISSOLO HÁPLICO Carbonático típico) } \\
\hline & $\mathrm{A}$ & $0-10$ & 70 & 15 & 15 & Sandy Loam & 2.46 & 10YR 5/4 \\
\hline & $\mathrm{Bi}$ & $10-60$ & 65 & 18 & 17 & Sandy Loam & 2.47 & 10YR 6/6 \\
\hline & $\mathrm{C}$ & $60-90$ & 54 & 29 & 17 & Sandy Loam & 2.55 & $2.5 \mathrm{Y} 8 / 1$ \\
\hline & $2 \mathrm{C}$ & $90-110$ & 19 & 73 & 8 & Silty Loam & 2.36 & $2.5 \mathrm{Y} 6 / 2$ \\
\hline & $3 \mathrm{C}$ & $110-130$ & 53 & 34 & 13 & Sandy Loam & 2.41 & 2.5 Y $7 / 2$ \\
\hline & $4 \mathrm{C}$ & $130-147$ & 60 & 23 & 17 & Sandy Loam & 2.45 & $2.5 \mathrm{Y} 6 / 6$ \\
\hline & $5 \mathrm{C}$ & $147-190$ & 93 & 2 & 5 & Sandy Loam & 2.55 & 10YR 6/8 \\
\hline AAPI & \multicolumn{8}{|c|}{ Profile 2 Oxisol (LATOSSOLO AMARELO Eutrófico típico) } \\
\hline & A & $0-20$ & 85 & 4 & 11 & Loamy Sand & 2.44 & 10 YR $6 / 3$ \\
\hline & BA & $20-40$ & 83 & 3 & 14 & Sandy Loam & 2.51 & $7.5 \mathrm{YR} 7 / 2$ \\
\hline & $\mathrm{Bw}$ & $40-110$ & 76 & 3 & 21 & Sandy Clay Loam & 2.45 & $7.5 \mathrm{YR} 7 / 2$ \\
\hline & $\mathrm{C}$ & $110-170$ & 74 & 3 & 23 & Sandy Clay Loam & 2.51 & $7.5 \mathrm{YR} 8 / 2$ \\
\hline $\mathrm{ACAG}$ & \multicolumn{8}{|c|}{ Profile 3 Ultisol (ARGISSOLO VERMELHO AMARELO Eutrófico típico) } \\
\hline & AP & $0-16$ & 88 & 4 & 8 & Loamy Sand & 2.48 & 10YR 5/3 \\
\hline & $\mathrm{Bt}$ & $16-37$ & 83 & 2 & 15 & Sandy Loam & 2.52 & 2.5 Y $7 / 4$ \\
\hline & $\mathrm{C}$ & $37-123$ & 71 & 3 & 26 & Sandy Clay Loam & 2.53 & $2.5 \mathrm{Y} 7 / 4$ \\
\hline ACAG & \multicolumn{8}{|c|}{ Profile 4 Oxisol (LATOSSOLO AMARELO Eutrófico típico) } \\
\hline & A & $0-16$ & 78 & 6 & 16 & Sandy Loam & 2.45 & 10YR 5/2 \\
\hline & Bw & $16-50$ & 68 & 6 & 26 & Sandy Clay Loam & 2.54 & 10YR 6/4 \\
\hline & $\mathrm{C}$ & $50-100$ & 40 & 15 & 45 & Clay & 2.54 & $5 Y R 7 / 6$ \\
\hline & Cpetrop & $100-110^{+}$ & 53 & 19 & 28 & Sandy Clay Loam & 2.56 & $7.5 \mathrm{YR} 5 / 8$ \\
\hline ACP & \multicolumn{8}{|c|}{ Profile 5 Ultisol (ARGISSOLO AMARELO Eutrófico abrúptico) } \\
\hline & A & $0-15$ & 89 & 4 & 7 & Sandy & 2.68 & 10YR 5/3 \\
\hline & $\mathrm{Bt}$ & $15-90$ & 84 & 2 & 14 & Sandy Loam & 2.58 & 10 YR $6 / 6$ \\
\hline & $\mathrm{C}$ & $90-150$ & 76 & 3 & 21 & Sandy Clay Loam & 2.68 & 10 YR $7 / 4$ \\
\hline & $\mathrm{Cr}$ & $150-170$ & 79 & 3 & 18 & Sandy Loam & 2.67 & 10 YR $7 / 6$ \\
\hline & Cpetrop & $170-200$ & 77 & 4 & 19 & Sandy Loam & 2.55 & $10 \mathrm{YR} 7 / 4$ \\
\hline $\mathrm{AVC}$ & \multicolumn{8}{|c|}{ Profile 6 Inceptisol (CAMBISSOLO HÁPLICO Tb Eutrófico tipico) } \\
\hline & AP1 & $0-10$ & 81 & 6 & 13 & Sandy Loam & 2.51 & 10YR 4/4 \\
\hline & AP2 & $10-30$ & 65 & 6 & 29 & Sandy Clay Loam & 2.51 & 7.5YR 4/6 \\
\hline & $\mathrm{ABi}$ & $30-50$ & 67 & 9 & 24 & Sandy Clay Loam & 2.49 & 10YR 5/6 \\
\hline & Bil & $50-85$ & 68 & 9 & 23 & Sandy Clay Loam & 2.58 & 10 YR 5/6 \\
\hline & $\mathrm{Bi} 2$ & $85-120$ & 62 & 12 & 26 & Sandy Clay Loam & 2.55 & 10 YR $6 / 6$ \\
\hline & $\mathrm{Bi} 3$ & $120-150$ & 62 & 15 & 23 & Sandy Clay Loam & 2.53 & 10 YR $5 / 8$ \\
\hline & $\mathrm{BiC}$ & $150-170$ & 69 & 13 & 18 & Sandy Clay Loam & 2.57 & 7.5 YR 5/8 \\
\hline & Subpetrop & $170+$ & 54 & 19 & 27 & Sandy Clay Loam & 2.51 & 7.5 YR 5/8 \\
\hline AVC & \multicolumn{8}{|c|}{ Profile 7 Inceptisol (CAMBISSOLO HÁPLICO Tb Eutrófico tipico) } \\
\hline & A & $0-5$ & 74 & 11 & 15 & Sandy Loam & 2.41 & $7.5 \mathrm{YR} 3 / 2$ \\
\hline & BA & $5-12$ & 77 & 6 & 17 & Sandy Loam & 2.47 & 7.5YR 4/3 \\
\hline & Bil & $12-30$ & 76 & 5 & 19 & Sandy Loam & 2.54 & $7.5 \mathrm{YR} 4 / 3$ \\
\hline & $\mathrm{Bi} 2$ & $30-80$ & 52 & 6 & 42 & Sandy Clay & 2.56 & 10YR 3/6 \\
\hline & $\mathrm{BC}$ & $80-110$ & 52 & 8 & 40 & Sandy Clay & 2.52 & $10 \mathrm{YR} 4 / 6$ \\
\hline & $\mathrm{CB}$ & $110-170$ & 57 & 3 & 40 & Sandy Clay & 2.54 & 10 YR $6 / 3$ \\
\hline
\end{tabular}

Hor. - Horizon; Dp - particle density; APOC - Sheep and goat grazing area; AAPI - Beekeeping area; ACAG - area of agroecological cultivation of vegetables; ACP - area of preserved Caatinga; AVC - Area of conventional production "Velha Chica".

Profiles 2 and 4 - Oxisols (LATOSSOLO AMARELO Eutrófico típico) and 3 and 5 - Ultisols (ARGISSOLO VERMELHO AMARELO Eutrófico típico and ARGISSOLO AMARELO Eutrófico abrúptico) had increments in the sand fraction in surface and reduction of clay fraction in subsurface, in the diagnostic horizons ( $\mathrm{Bw}$ and $\mathrm{Bt}$ ), an inherent feature of the studied classes. This result is 
Ethnopedology in production...

corroborated by Santos et al. (2010), because of the mechanism of translocation and consequent increase in the textural gradient in Ultisols, which contributes to the high sand contents compared with clay contents in surface.

In Inceptisol profiles (P1, P6 and P7) the textural classification varied between sandy loam, silty loam, sandy clay loam and sandy clay. For Oxisol profiles (P2 and P4), the textural classification varied between loamy sand, sandy loam and sandy clay loam. For profiles classified as Ultisols (P3 and P5), texture variation corresponded to loamy sand, sandy loam and sandy clay loam (Table 1).

Particle density $(\mathrm{Dp})$ varied in the studied profiles from 2.41 to $2.68 \mathrm{~kg} \mathrm{dm}^{-3}$, indicating mineral soils, because particle density refers to the solids of the soil, i.e., its matrix, which contains inorganic and organic fractions. Inorganic fractions are difficult to change, i.e., they are stable, inherent to the parent material (FERREIRA, 2010).Regarding soil classification with respect to color, in all horizons there was a predominance of more yellowish hues (2.5Y to 10YR) with higher chromas, except the $\mathrm{C}$ horizon of profile 4 , which showed a more reddish hue (5YR) (Table 1). Soil color characterization by the popular knowledge was consistent with the etic classification, since the farmers observed predominance of lighter colors in the profiles, except in P4 (Oxisol), and P6 and P7 (Inceptisols).

The results of soil chemical analysis of the production units are described in Table 2. Soil $\mathrm{pH}$ varied in the different soil classes, with higher values in the Inceptisols (P1, P6 and P7), ranging from 5.8 (intermediate acidity) to 9.9, indicating high alkalinity due to the base cations, particularly $\mathrm{Ca}^{2+}$, which contributes to soil alkalinity and increase in the $\mathrm{pH}$; hydrogen and aluminum are replaced by these cations, by permanent charges, regardless of $\mathrm{pH}$.

Oxisols (P2 and P4) and Ultisols (P3 and $\mathrm{P} 5)$ showed lower $\mathrm{pH}$ values, 4.0 (high acidity), with presence of $\mathrm{Al}^{3+}$ and $\mathrm{H}^{+}$at 7.5 (weak alkalinity) and presence of base cations $\left(\mathrm{Ca}^{2+}, \mathrm{Mg}^{2+}\right.$ and $\left.\mathrm{Na}^{+}\right)$, contributing to the eutrophic character, with high base saturation, equal to or greater than $50 \%$ (Table 2). Ker (1997) considers that the class of Oxisols is strongly influenced by pedogenetic processes, especially climate (pluvial precipitation), responsible for intense chemical weathering. Depending on the climatic pattern, it is possible to find less weathered Oxisols in less stable region,
CUNHA, M. S. et al.

with the predominance of kaolinite, thus having less leaching of the base cations and eutrophic character, as found in this study.

Electrical conductivity (EC) was considered as low in all profiles, except in the Inceptisol (P1) (APOC) in subsurface, in which there was an increment in $\mathrm{pH}$, leading to higher EC (Table 2). According to Carmo et al. (2016), the EC is positively correlated with $\mathrm{Ca}^{2+}$ and $\mathrm{Mg}^{2+}$ contents, base saturation $(\mathrm{V})$ levels and with the contents of nutrients.

For total organic carbon (TOC), there was no expressive variation in the different production units due to the soil management practices and agricultural crops used by the farmers, because their introduction changes the structural, chemical and biological properties (Table 2). However, highest values were found in the Inceptisols (P1, P6 and $\mathrm{P} 7)$, especially in the sheep and goat grazing area (APOC - P1) and in the conventional production area "Velha Chica" (AVC - P6 and P7), which were related to the supply and accumulation of animal waste (manure) and crop residues (organic residues), associated with their quality, maintaining the stable state of TOC (LOSS et al., 2012; BEZERRA et al., 2013). In general, the soils had low $\mathrm{P}$ contents (Table 2), which can be explained by the parent material, limestone from the Jandaíra Formation. Costa et al. (2011) also detected low P contents in calcareous Inceptisols in a study conducted in Rio Grande do Norte. In general, Brazilian soils are poor in $\mathrm{P}$, especially in semi-arid regions.

$\mathrm{K}^{+}$contents were low and the most expressive values were found in the areas ACAG (P3 and P4) and AVC (P7), specifically in their diagnostic horizons [Bt $\left(5.7 \mathrm{mg} \mathrm{dm}^{-3}\right)$, Bw $(5.8 \mathrm{mg}$ $\left.\mathrm{dm}^{-3}\right)$ and $\mathrm{Bi}\left(5.2 \mathrm{mg} \mathrm{dm}^{-3}\right)$, respectively]. Higher $\mathrm{Na}^{2+}$ contents were found in soil profiles with higher values of clay fraction, specifically the Inceptisols (Table 2). This result is mainly due to the high cation exchange capacity, related to the parent material.

$\mathrm{Ca}^{2+}$ contents were high particularly in the profiles 1, 4, 6 and 7, with variation of $\mathrm{Mg}^{2+}$ in the horizons and profiles of the studied areas, and the Inceptisol (CAMBISSOLO HÁPLICO Tb Eutrófico típico) (P7) showed higher values than the others. It is an area with predominance of Inceptisols, originated from Jandaíra limestone (IDEMA, 2008). The Oxisols showed high values, due to the climatic pattern, which reduces chemical weathering and the leaching of bases (Table 2). 
Tabela 2. Soil chemical attributes in the areas of the family farming production unit Canto de Ilha de Cima, São Miguel do Gostoso, RN.

\begin{tabular}{|c|c|c|c|c|c|c|c|c|c|c|c|c|c|c|c|}
\hline \multirow[t]{2}{*}{ Area } & \multirow[t]{2}{*}{ Hor. } & \multirow{2}{*}{$\begin{array}{c}\text { Layer } \\
\mathrm{cm}\end{array}$} & \multirow[t]{2}{*}{$\mathrm{pH}$} & \multirow{2}{*}{$\begin{array}{c}\text { EC } \\
\mathrm{ds} / \mathrm{m}\end{array}$} & \multirow{2}{*}{$\begin{array}{c}\text { TOC } \\
\mathrm{g} \mathrm{kg}^{-1}\end{array}$} & $\mathrm{P}$ & $\mathrm{K}$ & $\mathrm{Na}$ & $\mathrm{Ca}^{2+}$ & $\mathrm{Mg}^{2+}$ & SB & $\mathrm{Al}^{3+}$ & $\mathrm{H}+\mathrm{Al}$ & CEC & \multirow{2}{*}{$\begin{array}{l}\mathrm{V} \\
\%\end{array}$} \\
\hline & & & & & & \multicolumn{3}{|c|}{$\mathrm{mg} \mathrm{dm}^{-3}$} & \multicolumn{6}{|c|}{$\mathrm{cmol} \mathrm{dm}{ }^{-3}$} & \\
\hline \multirow[t]{8}{*}{ APOC } & \multicolumn{15}{|c|}{ Profile 1 Inceptisol (CAMBISSOLO HÁPLICO Carbonático típico) } \\
\hline & A & $0-10$ & 8.9 & 0.1 & 1.5 & 0.6 & 4.6 & 4.9 & 6.7 & 1.5 & 17.7 & 0.0 & 0.5 & 18.2 & 97.0 \\
\hline & $\mathrm{Bi}$ & $10-60$ & 8.9 & 0.5 & 1.4 & 0.5 & 3.4 & 2.3 & 5.5 & 1.6 & 12.8 & 0.0 & 0.5 & 13.3 & 96.0 \\
\hline & $\mathrm{C}$ & $60-90$ & 9.0 & 3.3 & 1.1 & 0.6 & 2.9 & 2.5 & 6.3 & 3.7 & 15.4 & 0.0 & 0.5 & 15.9 & 97.0 \\
\hline & $2 \mathrm{C}$ & $90-110$ & 9.2 & 5.0 & 1.0 & 0.5 & 2.4 & 2.4 & 5.7 & 4.1 & 14.6 & 0.0 & 0.2 & 14.8 & 99.0 \\
\hline & $3 \mathrm{C}$ & $110-130$ & 9.3 & 4.2 & 1.0 & 0.5 & 2.2 & 1.9 & 5.9 & 3.6 & 13.6 & 0.0 & 0.7 & 14.3 & 95.0 \\
\hline & $4 \mathrm{C}$ & $130-147$ & 9.4 & 4.6 & 0.8 & 0.5 & 2.1 & 2.1 & 5.9 & 3.7 & 13.8 & 0.0 & 0.5 & 14.3 & 97.0 \\
\hline & $5 \mathrm{C}$ & $147-190$ & 9.0 & 1.2 & 0.5 & 0.7 & 2.2 & 1.9 & 4.6 & 1.8 & 10.5 & 0.0 & 0.3 & 10.8 & 97.0 \\
\hline \multirow[t]{5}{*}{ AAPI } & \multicolumn{15}{|c|}{ Profile 2 Oxisol (LATOSSOLO AMARELO Eutrófico típico) } \\
\hline & A & $0-20$ & 7.5 & 0.0 & 1.1 & 0.6 & 2.3 & 2.6 & 1.8 & 1.0 & 7.7 & 0.0 & 2.6 & 10.3 & 75.0 \\
\hline & BA & $20-40$ & 7.3 & 0.0 & 1.1 & 0.5 & 2.3 & 2.8 & 1.7 & 1.1 & 7.9 & 0.0 & 2.0 & 9.9 & 80.0 \\
\hline & $\mathrm{Bw}$ & $40-110$ & 6.8 & 0.0 & 1.1 & 0.7 & 2.3 & 3.3 & 1.6 & 0.8 & 8.0 & 0.0 & 2.0 & 10.0 & 80.0 \\
\hline & $\mathrm{C}$ & $110-170$ & 4.9 & 0.0 & 1.0 & 0.6 & 2.1 & 3.3 & 1.3 & 0.6 & 7.3 & 0.2 & 2.0 & 9.3 & 78.0 \\
\hline \multirow[t]{4}{*}{$\mathrm{ACAG}$} & \multicolumn{15}{|c|}{ Profile 3 Ultisol (ARGISSOLO VERMELHO AMARELO Eutrófico típico) } \\
\hline & AP & $0-16$ & 6.2 & 0.0 & 1.1 & 0.7 & 5.1 & 2.4 & 3.2 & 1.7 & 12.4 & 0.1 & 2.3 & 14.7 & 84.0 \\
\hline & $\mathrm{Bt}$ & $16-37$ & 6.6 & 0.1 & 1.3 & 0.6 & 5.7 & 2.4 & 1.4 & 1.2 & 10.7 & 0.1 & 1.7 & 12.4 & 87.0 \\
\hline & $\mathrm{C}$ & $37-123$ & 4.0 & 1.4 & 1.1 & 0.5 & 5.5 & 2.8 & 3.5 & 2.3 & 14.1 & 0.2 & 2.5 & 16.6 & 85.0 \\
\hline \multirow[t]{5}{*}{$\mathrm{ACAG}$} & \multicolumn{15}{|c|}{ Profile 4 Oxisol (LATOSSOLO AMARELO Eutrófico típico) } \\
\hline & A & $0-16$ & 6.1 & 0.1 & 0.9 & 0.5 & 5.0 & 3.1 & 4.0 & 1.7 & 13.8 & 0.1 & 2.5 & 16.3 & 85.0 \\
\hline & $\mathrm{Bw}$ & $16-50$ & 5.8 & 0.1 & 0.9 & 0.4 & 5.8 & 2.4 & 2.2 & 1.1 & 11.5 & 0.1 & 2.8 & 14.3 & 80.0 \\
\hline & $\mathrm{C}$ & $50-100$ & 4.1 & 0.2 & 0.8 & 0.4 & 2.1 & 4.9 & 2.6 & 0.9 & 10.5 & 0.2 & 3.3 & 13.8 & 76.0 \\
\hline & Cpetrop & $100-110^{+}$ & 9.7 & 0.1 & 0.8 & 0.4 & 2.3 & 4.7 & 6.7 & 2.6 & 16.3 & 0.0 & 0.6 & 17.0 & 96.0 \\
\hline \multirow[t]{6}{*}{$\mathrm{ACP}$} & & & & file $5 \mathrm{U}$ & Itisol $(A$ & $R G I S S$ & $O L O$ & $A M A$ & $O E u t$ & f́fico al & rúpticc & & & & \\
\hline & A & $0-15$ & 6.1 & 0.0 & 1.1 & 0.4 & 3.5 & 2.4 & 2.7 & 1.1 & 9.7 & 0.1 & 3.0 & 12.7 & 77.0 \\
\hline & $\mathrm{Bt}$ & $15-90$ & 6.0 & 0.0 & 1.0 & 0.4 & 3.0 & 1.9 & 1.1 & 1.5 & 7.5 & 0.0 & 1.7 & 9.2 & 82.0 \\
\hline & $\mathrm{C}$ & $90-150$ & 6.1 & 0.0 & 0.9 & 0.4 & 2.4 & 3.3 & 1.0 & 2.1 & 8.8 & 0.0 & 1.7 & 10.5 & 84.0 \\
\hline & $\mathrm{Cr}$ & $150-170$ & 6.1 & 0.0 & 0.9 & 0.4 & 2.7 & 4.0 & 0.8 & 2.1 & 9.6 & 0.1 & 1.3 & 10.9 & 88.0 \\
\hline & Cpetrop & $170-200$ & 6.6 & 0.1 & 0.5 & 0.4 & 2.7 & 2.1 & 0.9 & 1.7 & 7.4 & 0.0 & 1.7 & 9.1 & 82.0 \\
\hline AVC & & & Prof & e 6 Inc & eptisol ( & $A M B$ & ISSOI & $\mathrm{OH}$ & $I C O I$ & Eutró & co tipi & & & & \\
\hline & AP1 & $0-10$ & 8.0 & 0.0 & 1.5 & 0.4 & 4.4 & 2.8 & 5.2 & 2.0 & 14.4 & 0.0 & 1.7 & 16.1 & 90.0 \\
\hline & AP2 & $10-30$ & 8.7 & 0.1 & 1.1 & 1.4 & 4.7 & 2.8 & 6.2 & 1.2 & 14.9 & 0.0 & 2.0 & 16.9 & 88.0 \\
\hline & $\mathrm{ABi}$ & $30-50$ & 9.5 & 0.1 & 1.0 & 0.8 & 3.2 & 5.2 & 6.7 & 2.1 & 17.2 & 0.0 & 0.5 & 17.7 & 97.0 \\
\hline & Bi1 & $50-85$ & 9.4 & 0.2 & 1.0 & 0.7 & 2.5 & 1.9 & 5.8 & 2.2 & 12.4 & 0.0 & 0.8 & 13.2 & 94.0 \\
\hline & $\mathrm{Bi} 2$ & $85-120$ & 9.9 & 0.1 & 0.9 & 1.4 & 2.3 & 2.0 & 5.1 & 2.1 & 11.5 & 0.0 & 0.5 & 12.0 & 96.0 \\
\hline & $\mathrm{Bi} 3$ & $120-150$ & 9.6 & 0.2 & 0.8 & 0.7 & 2.1 & 2.4 & 5.8 & 1.3 & 11.6 & 0.0 & 0.7 & 12.3 & 95.0 \\
\hline & $\mathrm{BiC}$ & $150-170$ & 9.4 & 0.2 & 0.5 & 1.0 & 2.1 & 3.5 & 4.9 & 2.2 & 12.7 & 0.0 & 0.5 & 13.2 & 96.0 \\
\hline & ubpetrop & $170+$ & 9.0 & 0.3 & 0.5 & 0.6 & 2.1 & 4.4 & 6.8 & 2.8 & 16.1 & 0.0 & 0.5 & 16.6 & 97.0 \\
\hline $\mathrm{AVC}$ & & & Prof & e 7 Inc & ptisol ( & $A M B$ & ISSOI & $\mathrm{OH}$ & $I C O 1$ & Eutró & co tipi & & & & \\
\hline & A & $0-5$ & 5.8 & 0.5 & 1.2 & 0.6 & 2.2 & 5.1 & 1.4 & 15.1 & 23.8 & 0.2 & 10.4 & 34.2 & 70.0 \\
\hline & BA & $05-12$ & 6.1 & 0.1 & 1.2 & 1.0 & 2.1 & 2.8 & 1.6 & 7.1 & 13.6 & 0.3 & 5.4 & 19.0 & 71.0 \\
\hline & Bil & $12-30$ & 6.6 & 0.3 & 1.0 & 0.9 & 5.7 & 5.2 & 3.8 & 2.4 & 17.1 & 0.0 & 2.1 & 19.2 & 89.0 \\
\hline & $\mathrm{Bi} 2$ & $30-80$ & 7.5 & 2.9 & 1.0 & 0.6 & 2.5 & 4.9 & 8.3 & 5.3 & 21.0 & 0.0 & 0.8 & 21.8 & 96.0 \\
\hline & $\mathrm{BC}$ & $80-110$ & 7.9 & 2.8 & 0.9 & 0.7 & 5.6 & 5.5 & 6.5 & 4.9 & 22.5 & 0.0 & 0.3 & 22.8 & 99.0 \\
\hline & $\mathrm{CB}$ & $110-170$ & 8.6 & 2.1 & 0.5 & 0.7 & 5.0 & 3.8 & 6.2 & 3.3 & 18.3 & 0.0 & 0.2 & 18.5 & 99.0 \\
\hline
\end{tabular}

Hor. - Horizon; $\mathrm{pH}$ - hydrogen potential; EC - electrical conductivity; TOC - total organic carbon; P - phosphorus; K - potassium; Na sodium; $\mathrm{Ca}$ - calcium; $\mathrm{Mg}$ - magnesium; $\mathrm{Al}^{3+}$ - aluminum; $(\mathrm{H}+\mathrm{Al})$ - potential acidity; $\mathrm{SB}$ - sum of bases; CEC - cation exchange capacity; V - base saturation; APOC - Sheep and goat grazing area; AAPI - Beekeeping area; ACAG - area of agroecological cultivation of vegetables; ACP - area of preserved Caatinga; AVC - Area of conventional production "Velha Chica".

$\mathrm{Al}^{3+}$ was present in most of the horizons because most of the soils are formed from calcareous parent material, which causes its precipitation. Occurrence of $\mathrm{Al}^{3+}$ was observed in the area with predominance of Oxisols (P2 and P4) and Ultisols (P3 and P5) (Table 2). Zambrosi et al. 
Ethnopedology in production...

(2008), in a study conducted in Oxisols under direct planting, also found that $\mathrm{Al}^{3+}$ occurred predominantly complexed by organic carbon.

Cation exchange capacity (CEC) and base saturation $(\mathrm{V})$ varied between the production units, and areas with predominance of Inceptisols (P1, P6 and P7) showed the highest values, differing from the others (Table 2). The emic classification was closely related to the etic classification (Table 3 ) with respect to the attribute stickiness, since the farmers used the expression "pega nas sandálias" (sticking to the sandals) to refer to the soil. Thus, it can be associated with higher clay content, which leads to higher natural fertility, in the areas described as "Terra Boa", "Malhada do Boi" and "Velha Chica". It is worth highlighting that cation exchange capacity (CEC) and base saturation (V) were particularly influenced because they have the highest contents of $\mathrm{Ca}^{2+}$ and $\mathrm{Mg}^{+2}$ (due to the
CUNHA, M. S. et al.

calcareous parent material), which contributed to higher $\mathrm{V}$ and consequently higher CEC in the Inceptisols. Maia (2013) observed that the increase in CEC in areas more cultivated is mainly due to the increment in $\mathrm{Ca}^{2+}$ and $\mathrm{Mg}^{+2}$ contents in the soil, which contributed to the increase in sum of bases. Pignataro Netto et al. (2009) also reported that greater amount of organic matter on the surface may have contributed to the occurrence of higher CEC. The lowest values were found in the Oxisol (LATOSSOLO AMARELO Eutrófico típico), P2, in the beekeeping area (AAPI) (Table 2), with predominance of eutrophic character, due to the reduction in chemical weathering, with expressive values of the base cations. Ker (1997) considers Oxisols as polygenetic, since different climatic patterns influence their formation, reducing and/or accelerating chemical weathering due to the pluvial precipitation.

Table 3. Morphological attributes of the areas (emic characterization) in the family farming production units at Canto da Ilha de Cima, São Miguel do Gostoso/ RN, Brazil.

\begin{tabular}{|c|c|c|c|c|}
\hline \multirow[t]{3}{*}{ ATTRIBUTE } & APOC & AAPI & \multicolumn{2}{|c|}{$\mathrm{ACAG}$} \\
\hline & \multicolumn{4}{|c|}{ PROFILE } \\
\hline & 1 & 2 & 3 & 4 \\
\hline Texture & Fine sand & Fine sand & Fine sand & Fine sand \\
\hline Structure & Forming clods & Forming clods & Forming clods & Forming clods \\
\hline Infiltration & $\begin{array}{c}\text { Good } \\
\text { infiltration }\end{array}$ & Good infiltration & Good infiltration & Good infiltration \\
\hline Stickiness & $\begin{array}{c}\text { Sticks to the } \\
\text { sandals }\end{array}$ & $\begin{array}{c}\text { Does not stick to } \\
\text { the sandals }\end{array}$ & $\begin{array}{c}\text { Does not stick to } \\
\text { the sandals }\end{array}$ & $\begin{array}{c}\text { Does not stick to the } \\
\text { sandals }\end{array}$ \\
\hline Color & Light color & Light color & Light color & Dark color \\
\hline Physical impediment & Without & Without & Without & With \\
\hline Land name & $\begin{array}{l}\text { Terra boa or } \\
\text { Malhada do } \\
\text { boi }\end{array}$ & Terra de arisco & $\begin{array}{c}\text { Terra de arisco } \\
\text { branco } \\
\text { amarelado }\end{array}$ & Terra de piçarro \\
\hline Position on landscape & Highland & Highland & Highland & Highland \\
\hline \multirow[t]{3}{*}{ ATTRIBUTE } & $\mathrm{ACP}$ & & $\mathrm{AVC}$ & \\
\hline & \multicolumn{4}{|c|}{ PROFILE } \\
\hline & 5 & 6 & & 7 \\
\hline Texture & Fine sand & Fine sand & $\mathrm{Coa}$ & se sand \\
\hline Structure & Forming clods & Forming clods & Forn & ng clods \\
\hline Infiltration & $\begin{array}{c}\text { Poor } \\
\text { infiltration }\end{array}$ & Good infiltration & Good & afiltration \\
\hline Stickiness & $\begin{array}{l}\text { Does not stick } \\
\text { to the sandals }\end{array}$ & $\begin{array}{c}\text { Sticks to the } \\
\text { sandals }\end{array}$ & Sticks t & the sandals \\
\hline Color & Light color & Dark color & & x color \\
\hline Physical impediment & With & Without & & $V$ ith \\
\hline Land name & $\begin{array}{l}\text { Terra de } \\
\text { arisco }\end{array}$ & $\begin{array}{c}\text { Terra boa-Velha } \\
\text { Chica }\end{array}$ & Terra bo & Velha Chica \\
\hline Position on landscape & Highland & Highland & & wland \\
\hline
\end{tabular}

APOC - Sheep and goat grazing area; AAPI - Beekeeping area; ACAG - area of agroecological cultivation of vegetables; ACP - area of preserved Caatinga; AVC - Area of conventional production "Velha Chica". 
P1 - Inceptisol (CAMBISSOLO HÁPLICO Carbonático típico), sheep and goat grazing area (APOC) and P6 and P7 - Inceptisol (CAMBISSOLO HÁPLICO Tb Eutrófico típico), areas of conventional production "Velha Chica" (AVC), were described by the farmers as "terras do alto" (highlands) (P1 and P6) and "terras de baixada" (lowlands) (P7), and their textures were described as "areia fina" (fine sand) (P1 and P6) and "areia grossa" (coarse sand) (P7). Structure was described using the expression "forma torrões" (forming clods), whereas for infiltration the farmers said "molha bem a terra" (good infiltration). Stickiness was described as "prega nas sandálias" (sticking to the sandals) when moist. These soils exhibited light color (P1) and dark color (P6 and P7), with no physical impediment (P1 and P6) and with physical impediment (P7). P1 is referred to as "Terra boa" or "Malhada de Boi", whereas P6 and P7 are known as "Terra Boa" or "Velha Chica" (Table 3). This corroborates the etic classification with respect to the inorganic fractions of the soil, with predominance of the clay fraction, which has cohesion and adhesion forces and determines the natural fertility of the soil, and to the parent material, Jandaíra limestone (IDEMA, 2008).

The Oxisol (LATOSSOLO AMARELO Eutrófico típico) (P2), located in the beekeeping area (AAPI), was considered by the farmers as "terra do alto" (highland), and its texture was described as "areia fina com pedras" (fine sand with rocks). Its structure was described as "forma torrões" (forming clods); infiltration - "molha bem a terra" (good infiltration); stickiness - "não prega nas sandálias" (does not stick to the sandals). This soil had a light color and no physical impediment and was also called "Terra de arisco" (fine-sand soil) (Table 3 ). The report of the farmers is closely related to the etic classification, and the soils have good drainage with no physical impediment and little stickiness, indicating low activity of the clay fraction. It is worth highlighting that the eutrophic character is due to the reduction of chemical weathering caused by the local particularities. The Ultisol (ARGISSOLO VERMELHO AMARELO Eutrófico típico) (P3) and Ultisol (ARGISSOLO AMARELO Eutrófico abrúptico) (P5), situated in the agroecological area (ACAG) and preserved Caatinga (ACP), were described by the farmers as "terras do alto" (highlands), with the following attributes: texture - "area fina" (fine sand); structure - "forma torrões" (forming clods); water infiltration in the soil - "lenta, molha bem a terra em superficie e não chega a abrejar" (slow, good infiltration in surface and does not soak) (P3) and "não molha bem e apresenta impedimento fisico em profundidade" (poor infiltration with physical impediment in subsurface) (P5). Stickiness was described as "não chega a pregar nas sandálias" (does not stick to the sandals), and the soil has a light color and was called by the farmers "terra de arisco branco amarelado" (yellowish-white finesand soil) (P3) and "terra de arisco" (fine-sand soil), according to Table 3 . The characteristics reported by the farmers fit the character of the $\mathrm{Bt}$ (textural), the diagnostic horizon of the studied class, in which the densification in subsurface caused by pedogenetic processes interferes with water infiltration in the soil, due to the reduction in pore space (P5), leading to an abrupt Bt.

Profile 4 - Oxisol (LATOSSOLO AMARELO Eutrófico típico), located in the agroecological area (ACAG), also cultivated with vegetables, was classified by the farmers as "terra de alto" (highland) with the following attributes: texture "areia fina" (fine sand); structure - "não forma torrões" (does not form clods); water infiltration "molha bem a terra" (good infiltration); stickiness "não chega a pregar nas sandálias" (does not stick to the sandals); and color - "escura" (dark), being called "Terra de piçarro" (sandy soil) (Table 3). This report from the emic point of view is related to the petroplinthic $\mathrm{C}$ horizon, in the layer of 100-110+ cm (Table 2).

In the emic survey at the Settlement Project Canto da Ilha de Cima II, farmers classified as fertile and better for agricultural activities the following areas: "Terra Boa" or "Malhada do Boi" (P1) and "Velha Chica" or "Terra Boa" (P6 and P7). In the present study, emic and etic classifications were similar because the morphological attributes characterized based on different methodological criteria were closely related. Indeed, it has been confirmed by Silva (2015), in an ethnopedological study with Entisols (NEOSSOLOS) under different agricultural uses in the Santa Agostinha Settlement - RN, where emic and etic classifications were correlated, and the most relevant attributes perceived by the farmers for the emic characterization were soil color and consistency (wet). This study highlights the importance of knowledge exchange between farmers, which contributed to changes, related to the importance of preserving natural resources, by understanding the different potentials and limitations, and to new perspectives of coexistence with the semi-arid region.

In the emic survey, farmers described as fertile and better for agricultural activities the following areas: "Terra Boa" or "Malhada do Boi" 
(P1) and "Velha Chica" or "Terra Boa" (P6 and P7), corroborating the etic classification, based on the parent material, since these soils are classified as Inceptisols, which have higher natural fertility.
There were interrelationships between popular and scientific knowledges, allowing them to become closer.

RESUMO: Estudos etnopedológicos em unidade familiar tendem a contribuir com academia sobre a importância da troca de saberes, proporcionando a compreensão da realidade local de uma comunidade. Objetivou-se a realização de estudo etnopedológico no Projeto de Assentamento Canto da Ilha de Cima - RN, em unidades de produção e inferir sobre as suas inter-relações dos conhecimentos. Foram realizadas oficinas participativas e caminhadas transversais e a classificação dos solos por meio da Etnopedologia. Os solos foram classificados de forma eticista e emicista, respectivamente: CAMBISSOLO HÁPLICO Carbonático típico Inceptisol (Terra Boa Malhada de Boi) (P1); LATOSSOLO AMARELO Eutrófico típico - Oxisol (Terra de Arisco) (P2); ARGISSOLO VERMELHO AMARELO Eutrófico típico - Ultisol (Terra de Arisco Branco Amarelado) (P3); LATOSSOLO AMARELO Eutrófico típico - Oxisol (Terra de Piçarro) (P4); ARGISSOLO AMARELO Eutrófico abrúptico - Ultisol (Terra de Arisco) (P5) and CAMBISSOLO HÁPLICO Tb Eutrófico típico - Inceptisol (Terra Boa Velha Chica) (P6 and P7). Os agricultores denominaram no levantamento emicista como terras férteis e melhores para o desempenho das atividades agrícolas, nas seguintes áreas: Terra Boa ou Malhada do Boi (P1) e as áreas denominadas de Velha Chica ou Terra Boa (P6 e P7), corroborando com a classificação eticista, em função do material de origem, sendo classificadas como CAMBISSOLOS, com maior fertilidade natural.

PALAVRAS-CHAVE: Ciência do solo. Uso da terra. Semiárido.

\section{REFERENCES}

ARAÚJO, A. L.; ALVES, A. G. C.; ROMERO, R. E.; FERREIRA, T. O. Etnopedologia: uma abordagem das etnociências sobre as relações entre as sociedades e os solos. Ciência Rural, Santa Maria, v. 43, n. 5, p. 854860, May. 2013. http://dx.doi.org/10.1590/S0103-84782013000500016.

BEZERRA, R. P. M.; LOSS, A.; PEREIRA, M. G.; PERIN, A. Formas de carbono em Latossolo sob sistemas de plantio direto e integração lavoura-pecuária no cerrado, Goiás. Semina: Ciências Agrárias, Londrina, v. 34, n. 1, p. 2637-2654, Jan./Feb. 2013. http://dx.doi.org/10.5433/1679-0359.2013v34n6p2637.

CARMO, D. L.; SILVA, C. A. Condutividade elétrica e crescimento do milho em solos contrastantes sob aplicação de diversos níveis de calagem. Pesquisa Agropecuária Brasileira, Brasília, v. 51, n. 10, p. 17621772, Oct. 2016. http://dx.doi.org/10.1590/s0100-204x2016001000008.

COSTA, C. L. L.; BATISTA, J. E. B.; COSTA JÚNIOR, C. O.; SANTOS, A. P.; SILVA, M. L. Uso de adubo fosfatado na cultura do melão em solos de origem calcária. Revista Verde de Agroecologia e

Desenvolvimento Sustentável, Mossoró, v. 6, n. 1; p. 58-62, Jan./Mar. 2011.

FERREIRA, M. M. Caracterização física do solo. In: De Jong van Lier, Q. ed. Física do solo. Viçosa, MG: Sociedade Brasileira de Ciência do Solo; 2010. p.1-27.

IDEMA, Secretaria de Estado do Planejamento e das Finanças do Rio Grande do Norte. Idema - Instituto de Desenvolvimento Econômico e do Meio Ambiente. Perfil do Seu Município, São Miguel do Gostoso. v. 10, p. 1-23, 2008

KER, J. C. Latossolos do Brasil: Uma revisão. Geonomos, Belo Horizonte, v. 5, n. 1, p. 17- 40, Jan. 1997. https://doi.org/10.18285/geonomos.v5i1.187. 
LOSS, A., PEREIRA, M. G., PERIN, A., ANJOS, L. H. C. Carbon and nitrogen content and stock in no-tillage and crop-livestock integration systems in the Cerrado of Goias State, Brazil. Journal of Agricultural Science, Toronto, v. 4, n. 1 p. 96-105, Jan. 2012. http://dx.doi.org/10.5539/jas.v4n8p96.

ALVAREZ, V., V. H.; NOVAIS, R. F.; BARROS, N. F.; CANTARUTTI, R. B.; LOPES, A. S. Interpretação dos resultados das análises de solos. In: RIBEIRO, A. C.; GUIMARÃES, P. T. G.; ALVAREZ V., V. H. (Eds). Recomendações para o uso de corretivos e fertilizantes em Minas Gerais $5^{\mathrm{a}}$ Aproximação. Viçosa, MG, Comissão de Fertilidade do Solo do Estado de Minas Gerais, 1999. 359p.: il cap. 5, p. 25-32.

MAIA, C. E. Qualidade ambiental em solo com diferentes ciclos de cultivo do meloeiro irrigado. Ciência Rural, Santa Maria, v. 43, n. 4, p. 603-609, Apr. 2013. http://dx.doi.org/10.1590/S0103-84782013000400007.

MATOS, L. V.; KER, J. C.; CARDOSO, I. M.; LANI, J. L.; SCHAEFER, C. E. G. R. O conhecimento local e a etnopedologia no estudo dos agroecossistemas da comunidade quilombola de brejo dos crioulos. Sociedade $\boldsymbol{\&}$ Natureza, Uberlândia, v. 26, n. 3, p 497-510, Jul./Sep. 2014. http://dx.doi.org/10.1590/1982-451320140308.

MOTA, J. C. A.; FREIRE, A. G.; ASSIS JÚNIOR, R. N. Qualidade física de um cambissolo sob sistemas de manejo. Revista Brasileira de Ciência do Solo, Viçosa, v. 37, n. 1 p. 1196-1206, Jan. 2013. http://dx.doi.org/10.1590/S0100-06832013000500009.

PIGNATARO NETTO, I. T.; KATO, E.; GOEDERT, W. J. Atributos físicos e químicos de um Latossolo Vermelho Amarelo sob pastagens com diferentes históricos de uso. Revista Brasileira de Ciência do Solo, Viçosa, v. 33, n. 5, p. 1441-1448, May. 2009. http://dx.doi.org/10.1590/S0100-06832009000500034.

RESENDE, M.; KER, J.C. Chave para identificação dos solos brasileiros. In: Programa e resumos do XXIII Congresso Brasileiro de Ciência do solo, 23, Porto Alegre, 1991, 321 p.

SANTOS, A. C.; PEREIRA, M. G.; ANJOS, L. H. C.; BERNINI, T. A.; COOPER, M.; NUMMER, A. R.; FRANCELINO, M. R. Gênese e classificação de solos numa topossequência no ambiente de mar de morros do médio Vale do Paraíba do sul, RJ. Revista Brasileira de Ciência do Solo, Viçosa, v. 34 n. 1 p. 1297-1314, Jan. 2010. http://dx.doi.org/10.1590/S0100-06832010000400027.

SANTOS, H. G.; JACOMINE, P. K. T.; ANJOS, L. H. C. DOS; OLIVEIRA, V. A.; LUMBRERAS, J. F.; COELHO, M. R.; ALMEIDA, J. A. DE; ARAUJO FILHO, J. C.; OLIVEIRA, J. B.; CUNHA, T. J. F. Sistema Brasileiro de Classificação de Solos. 5. ed. rev. e ampl. Brasília, DF: Embrapa, 2018. 356p.

SILVA, J. F. Estudos etnopedológicos em Neossolos sob diferentes usos agrícolas no assentamento Santa Augostinha, RN. Dissertação (Mestrado em Manejo do solo e Água)- Mossoró-507 Rn, Universidade Federal Rural do Semi Árido(UFERSA) 68:il 2015.

TEIXEIRA, P. C.; DONAGEMA, G. K.; FONTANA, A.; TEIXEIRA, W. G. Manual de Métodos de Análise de Solo. 3.ed. Rio de Janeiro: Embrapa Solos, 2017. 575 p.

VERDEJO, M. E. Diagnóstico rural participativo: guia prático DRP. Brasília: MDA/Secretaria da Agricultura Familiar, 200662 p.

ZAMBROSI, F. C. B.; ALLEONI, L. R. F.; CAIRES, E. F. Liming and ionic speciation of an Oxisol under notill system. Scientia Agrícola, Piracicaba, v. 65, n. 1, p. 190-203, Jan. 2008. http://dx.doi.org/10.1590/S010390162008000200013 